\section{第14回日本喉頭科学会} 特別講演

\section{音声分析技術の最近の進歩}

一臨床応用を目指して一

\author{
粕 谷 英 樹 \\ Recent Progress in Speech Analysis Methods: \\ Toward Clinical Applications
}

\title{
Hideki Kasuya
}

Speech analysis methods can be divided into two classes, parametric and nonparametric. The parametric method includes a speech production model in the analysis process, while the nonparametric method does not. The former is exemplified by the well-established linear prediction analysis and the latter often utilizes short-term Fourier analysis. Recent progress in speech analysis methods can be found in an ARX (Auto-regressive with exogenous input) method, a parametric approach, as well as STRAIGHT (Speech Transformation and Representation using Adaptive Interpolation of weighted spectrum) method, a nonparametric approach. The ARX method incorporates a sophisticated ARX-based speech production model, making it possible to separately estimate glottal flow parameters and formants. Basic and clinical applications of the ARX method are presented in the field of voice and speech disorders, including acoustic evaluation of dysarthria, esophageal voice and dysphonia.

Key words：音声分析, ソース・フィルタモデル, ARX 分析合成, Dysarthria

\section{1.はじめに}

音声信号から必要な情報を得るための音声分析技術は, パラメトリックな (Parametric) 方法とノンパラメトリッ クな (Non-parametric) 方法に分けられる。音声生成過 程の音響学的なモデル（及びモデルのパラメータ）を分析 方法になんらかの形で含む場合がパラメトリック分析法, 含まない場合がノンパラメトリック分析法である. 音声生 成過程の音響学的モデルは, 一般にソース・フィルタモデ ル1) あるいはその拡張モデルであり, 当該モデルを数学 的に表現するのに必要なパラメータセットを含むことにな る.

パラメトリック分析法の代表的な例は，よく知られた線 形予測分析法 (Linear Prediction Analysis Method) である ${ }^{2}$ ． 無声音に対しては, 白色雑音（ソース）がフォ ルマントだけからなる声道フィルタを駆動して得られた出 力が音声信号であるとモデル化し，有声音に対しては，単 位インパルス (ソース) がフォルマントだけからなる声道 フィルタを駆動したモデルで表す．有声音に対してはこの このような単位インパルスの系列が音声の基本周期に対応 して準周期的に駆動音源になるという特徵がある。したがっ て, 線形予測分析に打いて求めるべきパラメー夕（音声パ ラメータ）は, 基本的には, インパルス（あるいは雑音）
音源と仮定したときの音源の大きさと，フォルマントだけ からなると仮定した声道フィル夕のフィル夕係数（あるい はフォルマント) である. 音声パラメー夕は上述の音響学 的モデルを介して分析的に求められるので, 測定したパラ メータだけから，もとの音声信号を完全に再現することは できない(不可逆的).このことがパラメトリックモデル の特徴の一つである.

一方，ノンパラメトリック分析法の代表的な例が短時間 フーリエ分析法 (Short-Term Fourier Analysis Method) である。この分析法では音声の生成に関する音響学的モデ ルは特に仮定せず, フーリエの理論に従って時間領域で表 現された音声信号を周波数領域に変換する. 周波数領域で は, 音声信号は各成分音の大きさと位相で表されるが, 音 声分析では, 成分音の大きさが特に大切である. また, 周 波数領域で成分音の大きさと位相で表された音声信号をそ のままフーリ工理論に従って時間領域に変換（フーリ工逆 変換）すると, 全く元の音声信号が再現される (可逆的). 一方，ケプストラム (Cepstrum) 分析法やウエーブレッ 卜分析法も, 音声生成過程の音響モデルを仮定しないとい う意味では，ノンパラメトリック分析法の一つであるが, 実際には, ケプストラムパラメータなどを圧縮して不可逆 的に利用する。

最近, パラメトリック分析法として, 声門体積流音源 
をモデルに内蔵したARX (Auto-Regressive with eXogenous Input) 分析 (合成法) が開発され ${ }^{3)}$ ，また， ノンパラメトリック分析法として, 短時間フーリエ分析に 基礎をおいた STRAIGHT （Speech Transformation and Representation using Adaptive Interpolation of weighted spectrum) 分析法が提案され4), 注目されてい る.これらの分析法は, 基本周波数の推定や音声信号の数 学的表現において, 従来の方法より一層精緻化した分析法 であるだけでなく, いずれの方法でも, 分析法と表裏一体 の関係にある合成法もかなり詳細に吟味されている点に特 徵がある. 講演では, ARX 分析法を中心にしながら，そ の考え方と原理を解説するとともに, 音声障害, 運動障害 性構音障害, 食道音声などの症例を取り上げ, 音声分析に よって何がわかるのか, どのような利用が可能か, につい て述べた.

STRAIGHT 分析法の詳しい説明は省略するが，簡単に 言えば，音声の周期的な性質によって引き起こされる周波 数スペクトルの変動を, 正確に推定した基本周期に応じて, 短時間フーリエ分析の条件（空）を巧みに設定することに よって，滑らかな時間・周波数スペクトルを得るものであ る.

\section{2. $A R X$ 分析法の原理}

2.1 音声生成のソース・フィルタモデル

音声生成のソース・フィルタモデルは, 図 1 に示すよう に, 音源で表された声門体積流 (有声音) あるいは乱流 (無声音) が, 声道フィル夕を経て空気中に放射されるこ とによって音声波になる，という簡単なモデルで表され， その音響学的理論は $\mathrm{Fant}^{1)}$ や Stevens ${ }^{5)}$ らによって確立 された.さらに,このモデルに「線形性」を仮定すること によって, 理工学の分野で古くから研究されている「線形

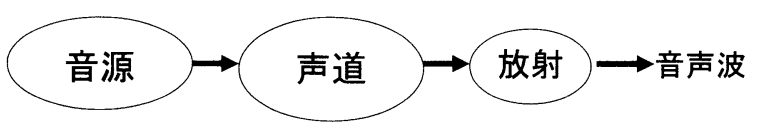

図 1 音声生成のソース・フィルタモデル

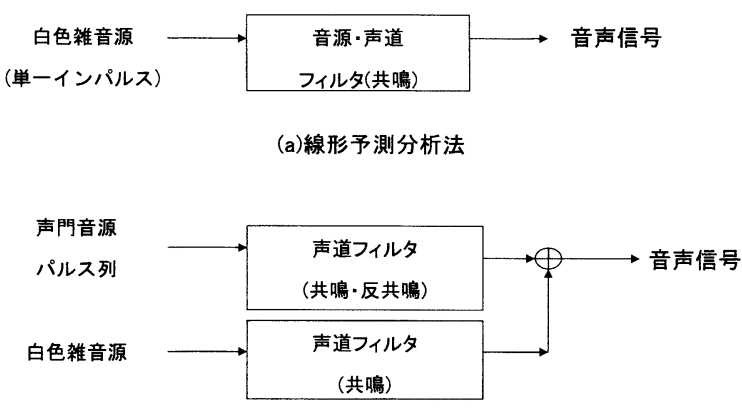

(b) ARX 分析法

図 2 線形予測分析法と ARX 分析法の音声生成 モデル
システム理論」を利用して，いろいろな角度から音声生成 過程の性質を調べることが可能になる，線形システムとは， 簡単に言えば，システムの入出力に比例関係が成り立つこ とであり, システムの要素（部分システム）の順番の入れ 替えが可能である。しかし，厳密に言えば，1）声門下部 構造との音響結合，2）音源と声道との音響結合（特に声 道の狭めが大きいとき)，3）声門開放時のフローリップ ル，4）声道の応答の次周期へのキャリーオーバー，5） 準周期的体積流と喉頭での乱流雑音の共存など，現実には 複雑な現象が起こっているのも事実である。また，音波が 声道内を平面波として伝搬する 1 次元波動で近似できるの は, せいぜい数 $\mathrm{kHz}$ 以下の周波数帯域に限られ，高い周 波数領域では，3 次元波動が優勢になる。それにもかかわ らず，1 次元波動伝搬に基礎をおいた線形性と各要素の独 立性を仮定した音声生成のソース・フィルタモデルは, 取 り扱いが簡単であるにもかかわらず，音声生成の近似モデ ルとして精度がよく, 多くの知見を提供してくれることも 事実なので, 線形ソース・フィル夕モデルに基づいた音声 分析・合成法が利用される。音声言語として重要な性質が 低い周波数帯域に集中して存在することがその根拠の一つ になっている.

\section{2 線形予測分析と $A R X$ 分析}

線形予測分析法 ${ }^{2)}$ と ARX 分析法 ${ }^{3)}$ の類似点 - 相違点 について述べる. 図 2（a），（b）に線形予測分析法及び ARX 分析法の仮定する音声生成モデルのブロック図を示 す.

線形予測分析法では（図 2（a ）), 音声信号は, 白色雑 音あるいは単一インパルスの音源・声道フィルタの応答で あると仮定する．音源のもつ周波数スペクトル特性は声道 の周波数伝達特性と区別できないため，両方の特性をまと めて音源・声道フィル夕特性として表す。さらに, フィル 夕の周波数特性は全極型（共鳴特性あるいはフォルマント だけ）によって表現するため, 時間領域では等価的に, 線 形予測（過去の音声信号值の線形結合によって現在の音声 信号值を予測するという，自己回帰型モデル）の式で表さ れることになる。このように単純な音声生成モデルを仮定 することによって，モデルパラメータ（フィルタの係数） の推定は非常に簡単になる. 分析（パラメータの推定）が 簡単であることが，線形予測分析法の最大の利点である.

一方，ARX 音声分析における音声生成過程のモデルは (図 $2(\mathrm{~b})$ ), 声門体積流音源パルス列が（単一インパル スではない), 極・零型の（共鳴と反共鳴，あるいは，フォ ルマントとアンチフォルマントをもつ) 声道フィルタを駆 動した出力と, 白色雑音が声道の共鳴特性を駆動した出力 との和で表されると仮定する。このことから分かるように， $\mathrm{ARX}$ 分析の方が線形予測分析に比べて, 前提にする音声 生成過程のモデルの近似度はよいことは明らかである。し かし，近似度がよいことの引き替えに，後述するように， 分析法は線形予測分析ほど単純ではなく, 繰り返し演算が 


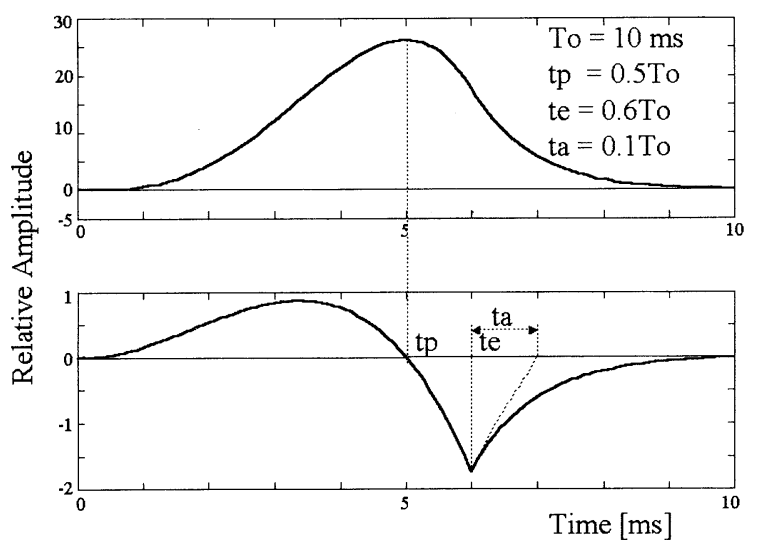

図 3 声門体積流（上）及び微分声門体積流波形 (下)

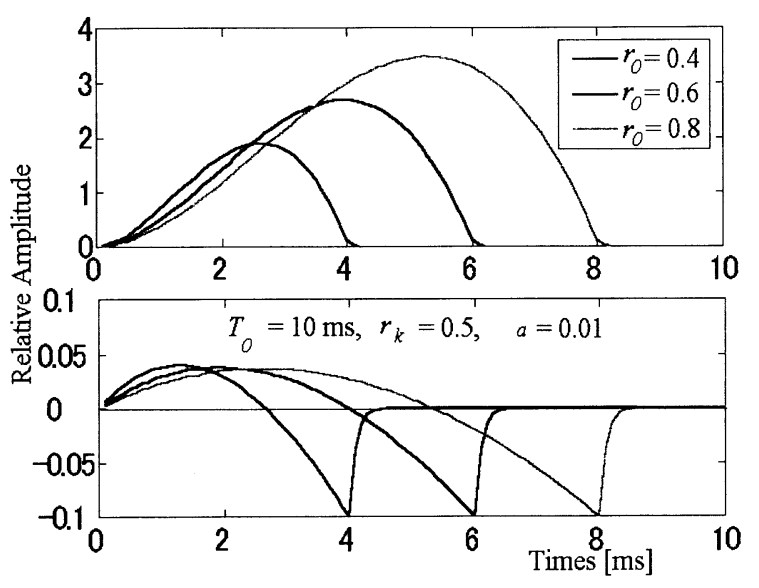

図 4（a）声門開放率 $r_{0}$ の変化に伴う声門体積流 （上）及び微分声門体積流波形（下）

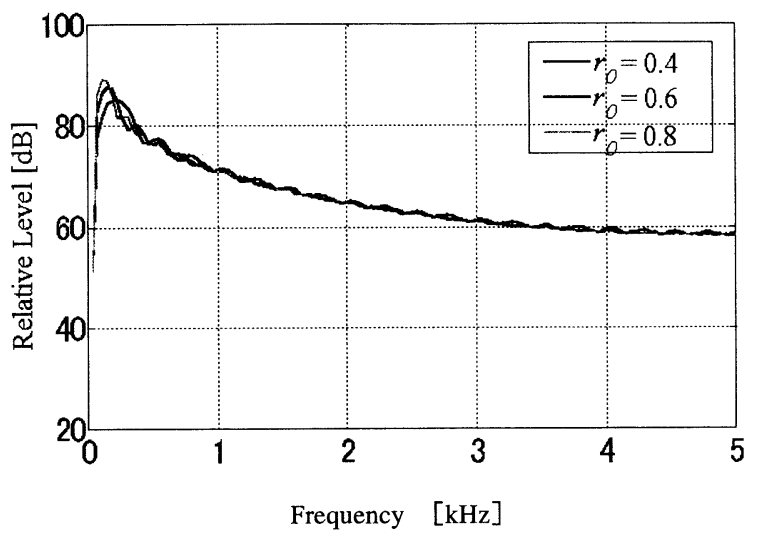

図 4 （b ） 声門開放率 $r_{0}$ の変化に伴う微分声門体積 流波形の周波数スペクトル
必要になる。

\section{$2.3 A R X$ 分析法}

\subsection{1 有声音源モデル}

声門体積流を表す記述モデルは数多く提案されている. 主なものに, Liljencrants-Fantのモデル6)（LFモデル）, Rosenberg-Klattのモデル ${ }^{7)}$ (RK モデル), RosenbergVeldhuis のモデル8)（RV モデル）などがある。それぞれ 一長一短があるが, 現在，LF モデルが標準モデルのよう な地位にある。ここでは， RV モデルを使ってモデルパラ メータのスペクトルに及活す効果について調へてみる.

図 3 の上がRV モデルで表した体積流波形であり，下 がその微分波形である. 口唇から空気中への放射特性は, 低い周波数ではほほ微分効果で近似できるので, 線形ソー ス・フィルタモデルの仮定に基づいて，図 1 の声道と放射 の順番を入れ替えて, 体積流波形に放射特性としての微分 を予め施し，微分声門体積流音源としてモデル化する．正 確に言うと，実は，まず微分声門体積流波形を数理的に表 し，それを積分したものを声門体積流音源とするのである. したがって，微分声門体積流波形は一般に不連続点をもつ. $\mathrm{RV}$ モデルによる微分声門体積流波形は，原点を０にする と，体積流は徐々に大きくなり $t_{p}$ で最大になる。その後 体積流は徐々に小さくなり， teで変化が最大になる。その 後緩やかに小さくなる。音声信号の決定要因として, 時刻 $t_{e}$ とそこでの微分声門体積流の負のピーク値 (励起振幅), そこから変化の仕方に関わる時定数 $t_{a}$ が特に重要である. 励起振幅が音声振幅に強く関わっている. 図では分かりや すくするために周期を $T_{0}=10 \mathrm{~ms}$ にしてある. 今，声開開 放率 $r_{0}$ を $t_{e} / T_{0}$, 帰還率 $r_{a}$ を $t_{a} / T_{0}$ として, それらの違い が周波数スペクトルに及ぼす効果を調べてみる.

図 4（a）は微分声門体積流波形の負のピーク值が一定 という条件で, 声門開放率 $r_{0}$ を0.4，0.6，0.8に変化させた ときの波形であり，図 4（b）はその周波数スペクトルで ある. 図からわかるように，励起振幅を一定にしながら声 門開放率を大きくするためには, 体積流の振幅や面積をか なり大きくしなければならないことが分かる。しかし，図 4（b）功分かるように声門開放率の周波数スペクトル 全体に与える効果は低周波数域に限られることが分かる. 一方，帰還率の効果はどうであろうか．図 5（a ），（b ） に $r_{a}$ の值を $0.01 ， 0.05,0.10$ と変化させた時の波形とスペ クトルを示す。ここでも，励起振幅を一定の条件で帰還率 を変えている，図から明らかなように帰還率の周波数スぺ クトルに及ぼす効果は大きい. 帰還率が 0.05 から0.01に $1 /$ 5 になるだけで， $3 \mathrm{kHz}$ での振幅レべルは約 $10 \mathrm{~dB} も 上$ 昇 する。

\subsubsection{ARX 音声生成モデル}

図 6 に ARX 音声生成モデルを示す。 $U(z)$ は上で述べ た離散時関系 (ディジタル系) で表した微分声門体積流, $B(z) / A(z)$ は声道特性, $A(z)$ はフォルマントを, $B(z)$ 


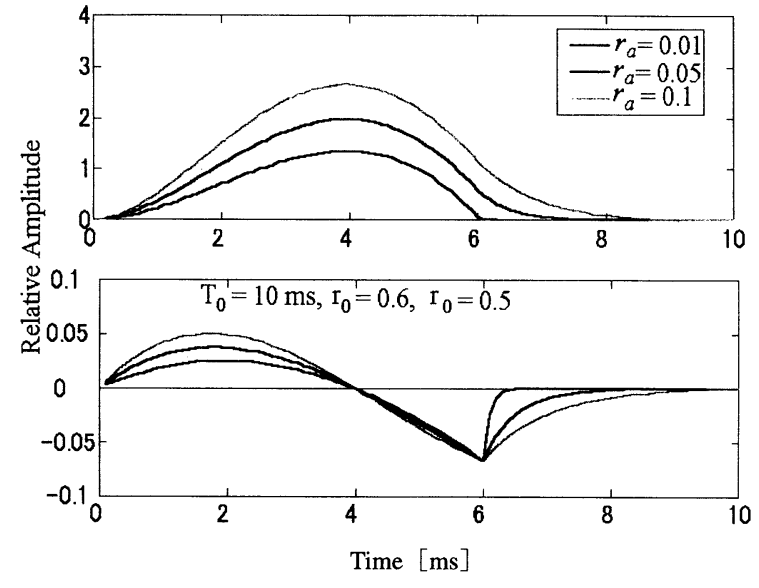

図 5 （a）帰還率 $r_{a}$ の変化に伴う声門体積流（上） 及び微分声門体積流波形（下）

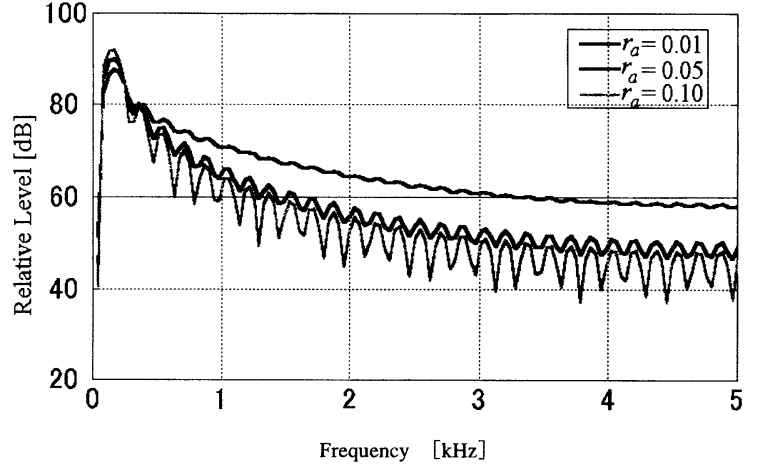

図 5 （b）帰還率 $r_{a}$ の変化に伴う微分声門体積流波 形の周波数スペクトル

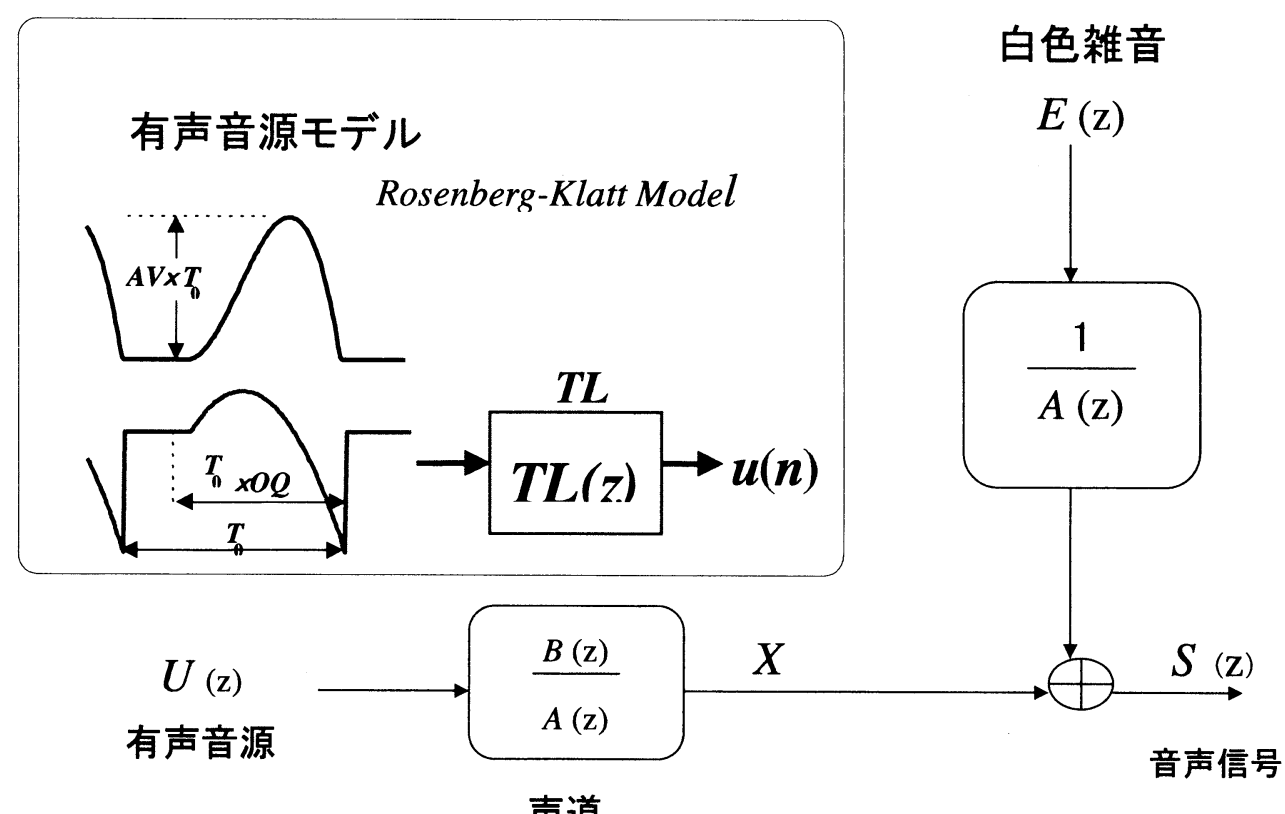

図 6 ARX 音声生成モデル

はアンチフォルマントを表す. $S(z)$ は音声信号である. これまで，筆者らの研究では，声門体積流モデルとして， 簡単さを理由に， RK モデルを用いているので，図の左上 にそのモデルを示す．2 次関数で近似された原波形がスペ クトル傾斜 TL（Tilt）をもつローパスフィル夕を通って $u(n)$ として得られる．TLを変化させることは近似的に 帰還率を変化させることに対応する. $U(z)$ は, $u(n)$ の $z^{-}$ 変換で, 実質的には同一のものである。 $E(z)$ は白色雑音 で, ARX モデルでは式誤差と呼ばれる.

2.3.3ARX 分析アルゴリズム

パラメトリック分析では, 音声生成過程をスキマティッ
クに言えば, $S=X^{*} Y$ と仮定し, $S$ (音声信号) を知って $X$ (音源特性) と $Y$ (声道特性) を求めるという問題であ る.ここで， *はかけ算のような操作である。線形予測分 析では，Xを白色雑音あるいはインパルスと仮定している ので, 求めるべきはその大きさだけであり，Sが分かれば, $Y$ を知ることはそれほど難しくないことが理解できよう。 しかも, 音源の周波数特性は $Y$ に含めることによって声 道特性と区別しないと割り切っているから, 問題の解法は 容易である。しかし，ARX 分析では，Xは2.3.2 節で 述べたようないろいろなパラメータを含む声門体積流であ り，Yは声道特性であることから， $S$ を知って $S=X^{*} Y$ を満足する $X$ と $Y$ を求めよ, という問題を解かなければ 


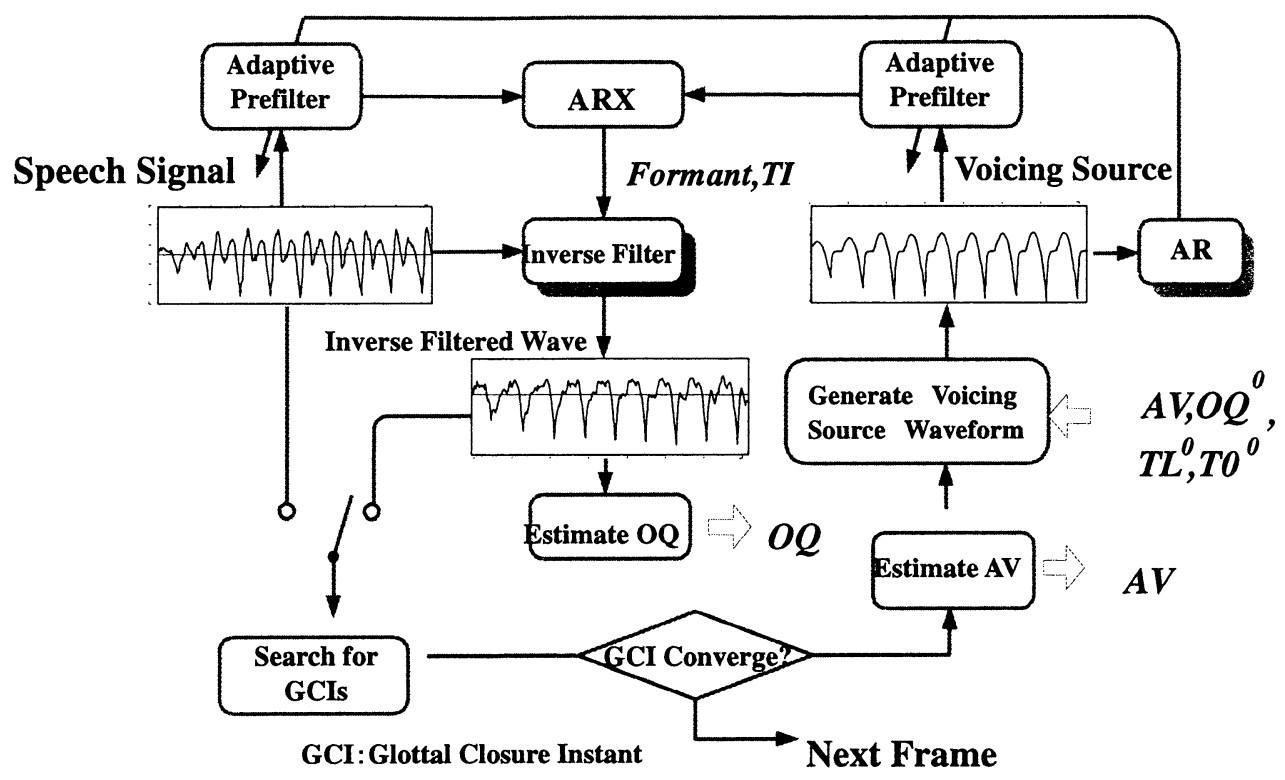

図 7 ARX 分析過程

ならない。この式を満足する $X$ と $Y$ の組合せは，理論的 には無限に存在する。仮に，*の操作をかけ算として， $S=$ 12 とすれば，積が12になる $X$ と $Y$ の組合せはいろいろあ る. 結局 $X$ と $Y$ の存在範囲に制限を加えながら， $S=12$ に なるような $X$ と $Y$ を繰り返し演算によって，もっとも “最適なもの”を求めることになる。 ARX 分析法が繰り 返し演算を含むことは，このような理由からである。

具体的な ARX 分析アルゴリズムを図 7 に示す．図の左 に描いてあるような観測空内の数周期からなる音声信号に 対して，図の右に示すように音源波形の非定常性（観測空 内で音源の特性が時間的に変化していること）を仮定しな がら, 声道特性には定常性を仮定し,（観測空内で声道特 性はほどんど変化していないということ), 声道フィル夕 特性を推定する (図の ARX ボックス). 声道特性の逆特 性をもつフィルタ（逆フィルタ）に観測空内の音声信号を 通して得られた音源波形（図の中央部）を参照して, 音源 パラメータを新たに推定し，右上のような音源波形を仮定 して, 再び声道フィルタ特性を推定する。このような操作 を繰り返して, 推定した微分声門体積流（逆フィルタの出 力）の励起点が変化しなくなったとき, あるいは繰り返し 演算を一定回数繰り返したとき，分析を終了し，次の観測 空 (フレーム) に移動する。経験的に 5 回以内の繰り返し で収束することが分かっている。このような操作を繰り返 すことによって，音源と声道のパラメータを分析する．

線形予測分析が, 有声音に対しては, 単一パルス音源に よる声道の駆動を仮定しているのに対して，ARX 分析で は，より現実に近い複数の“非定常な”音源パルス系列 を仮定して声道特性を推定する。このモデルの違いは，女 性や幼児・ 子供, 歌声のように高ピッチの音声に対して顕 著な違いになって現れる. ARX 分析法は, このような高 ピッチ音声に威力を発揮し, 特に第 1 フォルマント周波数

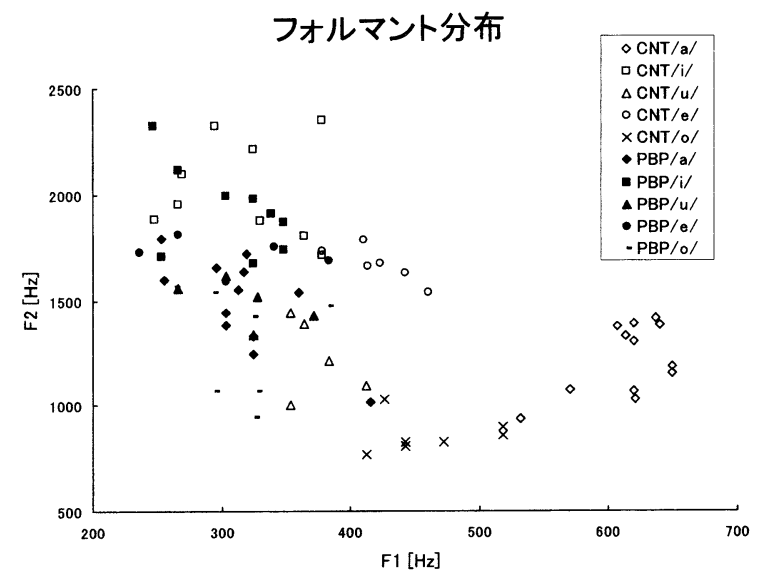

図8 健常者 $(\mathrm{CNT})$ と擬性球麻瘦患者 (PBP) の 文音声中の母音の第 1 , 第 2 フォルマント周波 数分布

の推定精度が, 線形予測分析に比べて際だってよいことが 明らかになっている3!).

また，紙幅の都合で詳細は省略するが，微分声門体積流 波形の高周波数成分の群遅延（位相の周波数微分值）特性 をランダムにすることによって, 気息性音声や嗄声も分析・ 再合成できることが分かっている $\left.{ }^{9}, 11,12\right)$.

\section{3. $A R X$ 分析の臨床応用}

\section{1 運動障害性構音障害症例の音響分析}

神経・筋系の疾患によって引き起こされる声 ・韻律・構 音の障害を調べるのに ARX 分析法が利用され, 興味深い 結果が得られている。運動障害性構音障害症例の多くでは, 嗄声, 基本周波数レンジの狭小化, 子音 -母音構音の不完 全性, などが知られている。体語ではさらに, アクセン 
ト句（アクセント単位を形成する韻律句）とイントネーショ ン句（イントネーション単位を形成する韻律句）が同一に なることに伴うリズムの単調性なども顕著である ${ }^{10,11)}$ 。こ こでは, ARX 分析によって得られた母音のフォルマント 周波数の例を示す.

図 8 は, 健常者 (CNT) と擬性球麻痺症例 (PBP) の 連続音声から ARX 分析によって測定した母音区間の中央 部の第 1 , 第 2 フォルマント周波数の分布を示す. / i/の 前舌狭母音は健常者と疾患症例ではほとんど違いはないが, 疾患例の $/ \mathrm{e}, \mathrm{u}, \mathrm{o}, \mathrm{a} / \mathrm{h}$, 特に後舌あるいは広母音のフォルマ ント周波数は不完全であり，舌の後部への運動，顎の開き の運動が障害されていることが分かる。このような音響分 析結果は, どのような構音運動が障害されているかを，定 量的に理解するのに役立つといえる.

また，ARX 分析合成技術を利用して，言語聴覚士がリ ハビリテーションの過程で聴覚的な評価指標として広く用 いる「モノトーン」な印象の実体を研究するのにも利用さ れている ${ }^{11)}$.このような症例では，一般的に嗄声を伴うた め, 高周波数域における音声の非周期的な性質を表現でき る分析法が必要であるが, 前に述べたように, ARX 分析 法はそのような表現力があるので都合がよい，症例音声の $\mathrm{ARX}$ 分析によって分析した基本周波数軌跡やフォルマン 卜周波数を，いろいろ修正して再合成した音声を聴取しな がら，「モノトーン」な印象に関係する音響パラメータの 性質を体系的に調べることができる．そのような知見から， 有効なリハビリテーションの指針などが得られるものと期 待される。

\section{2 食道音声の声質改善への応用}

喉摘者の食道音声は，通常音声に比べて，ラウドネスが 小さい，基本周波数が不安定である，気管孔雑音や空気捸 取時の雑音を伴う，無声子音が弱い，呼気段落が短い，抑 揚に乏しい，嗄声がある，女性でもピッチが低い，などの 特徵があるため, 食道発声者自身もその声質改善を希望し ている．食道音声には，上で述べた音源モデルは必ずしも 当てはまるわけではないが, ARX 分析法を適用して分析 した音声パラメータを修正して再合成することによって， 声質改善が可能な場合があることが知られている，女性の 低いピッチを高く，フォルマント周波数を若干高く，抑揚 を大きく，基本周波数を平滑化する，などの操作によって， 声質の改善が図られる。しかし, 多くの食道音声では, 「基本周波数や強度の不安定性」が顕著であるため, 基本 周波数の安定性を前提にしている ARX 分析法よりは，そ のような前提のないノンパラメトリックな分析法の一つで あるケプストラム法の方が安定に分析・再合成できるよう である ${ }^{12)}$.

\section{2 音声障害の評価への応用}

上で述べたように, ARX 分析法では声門体積流の励起 点を正確に求める過程を含んでいる。したがって，隣接す
る励起点時間間隔を基本周期と定義することによってジッ 夕を，励起振幅からシマを，それぞれ求めることが出来る。 従来の音声障害の音響的評価では13), 持続母音の音声波形 からジッ夕，シマなどを測定していたが，ARX 分析法に よって, 連続音声の近似的な音源波形からジッ夕やシマを 分析できることになって, 従来よりも新しい知見が得られ るものと期待される.

\section{4.おわりに}

パラメトリック及びノンパラメトリックな音声分析法の 最近の進歩, 特に, パラメトリック分析法の代表として ARX 分析法を取り上げ詳しく述べた. また，その音声言 語障害の基礎・臨床分野への応用例についても触れた。パ ラメトリック分析とは, 要するに音声生成過程を, $S=X^{*}$ $Y$ という方程式で近似し, $S$ (音声信号) を知って, $X, Y$ を求めよ, という不定方程式の解を求める問題に帰着する. 従って，不定方程式をいかに精密なものに仕上げていくか, そして原理的には無限に存在する解の中から, どのように 正解に近い解を求めるか, という課題がいぜんとして残っ ている. 音声生成過程に関する生理学的・音響学的研究の 進歩が音声分析モデルの精緻化に貢献し，その知見がよい 解を求めるアルゴリズムの発見に役立つことは言うまでも ない.

最後に, ALS に代表されるように, 病状の悪化に伴っ て, 音声言語によるコミュニケーション機能が悪化し, 最 後には失われていく場合に，音声分析合成技術を利用して， 病状の変化に応じて，一貫して支援する技術（Coherent Communication Aids）の開発が, 技術者にとっての挑 戦であると考えている，今後も，多くの若い研究者がこの ような分野で活躍することを祈って筆を置く.

\section{文献}

1) Fant G: Acoustic Theory of Speech Production (2nd ed.), Mouton: the Hague, 1970.

2) Markel JH \& Gray A : Linear Prediction of Speech, Springer-Verlag: New York, 1976.

3）大塚貴弘, 粕谷英樹 : 音源パルス列を考慮した頑健 な ARX 音声分析法. 日本音響学会誌 $58 ： 386$ 397, 2002.

4) Kawahara H, Masuda KI \& de Cheveigne A : Restructuring speech representations using a pitch-adaptive time-frequency smoothing and an instantaneous-frequency-based F0 extraction: Possible role of a repetitive structure in sounds, Speech Communication, 27: 187 207, 1999.

5) Stevens KN : Acoustic Phonetics, The MIT Press, 1998.

6) Fant G, Liljencrants $J$ \& Lin QG : A fourparameter model of glottal flow, Speech 
Transmisson Lab. QPSR 4:1 13, Royal Inst. of Tech., Stochholm, 1985.

7) Klatt DH \& Klatt L : Analysis, synthesis and perception of voice quality variations among female and male talkers, J. Acoust. Soc. Am., $87: 820 \sim 857,1990$.

8) Veldhuis $R:$ A computationally efficient alternative for the Liljencrants-Fant model and its perceptual evaluation, J. Acoust. Soc. Am., $103:$ 566 571, 1998.

9) Ohtsuka $\mathrm{T}$ \& Kasuya $\mathrm{H}$ : Aperiodicity control in ARX-based speech analysis-synthesis method, Proc. EUROSPEECH2001, Arlborg, Denmark, 3: 2267 2270, 2001.
10）廣瀬 肇：中枢神経障害と音声障害. 音声言語医学 $42: 121 \sim 128,2001$.

11）小林康統, 森 大毅, 粕谷英樹ほか：運動障害性構音 障害音声の音響的及び知覚的性質. 電子情報通信学 会技術研究報告 SP2002, 105, 2002.

12）秋元博樹, 藤井 圭, 森 大毅ほか：食道音声の声質 改善の試み。電子情報通信学会技術研究報告 SP2002, 107, 2002.

13）日本音声言語医学会編: 声の検查法 (第 2 版), 医歯 薬出版, 125 162, 1994.

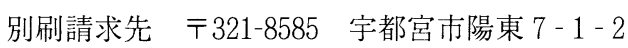
宇都宮大学工学部 粕谷英樹 